\title{
Development of partial rock veneers by root throw in a subalpine setting
}

\author{
W. R. Osterkamp, ${ }^{1 *}$ T. J. Toy ${ }^{2}$ and M. T. Lenart ${ }^{3}$ \\ US Geological Survey, 1675 West Anklam Road, Tucson, AZ 85745, USA \\ 2 University of Denver, Department of Geography, Denver, CO 80208, USA \\ 3 University of Arizona Institute for the Study of Planet Earth, 715 N. Park Street, Tucson, AZ 8572I, USA
}

* Correspondence to:

W. R. Osterkamp, US

Geological Survey, 1675

West Anklam Road, Tucson,

AZ 85745, USA.

E-mail:wroster@usgs.gov

Received 12 March 2004;

Revised I4 December 2004;

Accepted 17 January 2005

\begin{abstract}
Rock veneers stabilize hillslope surfaces, occur especially in areas of immature soil, and form through a variety of process sets that includes root throw. Near Westcliffe, Colorado, USA, data were collected from a $20 \times 500 \mathrm{~m}$ transect on the east slope of the Sangre de Cristo Mountains. Ages of pit/mound complexes with rock fragments exposed at the surface by root throw ranged from recent (freshly toppled tree) to unknown (complete tree decay). Calculations based on dimensions of the pit/mound complexes, estimated time of tree toppling, sizes of exposed rock fragments, and percentage rock covers at pit/mound complexes, as well as within the transect area, indicate that recent rates of root throw have resulted in only partial rock veneering since late Pleistocene deglaciation. Weathering of rock fragments prevents development of an extensive rock veneer and causes a balance, achieved within an estimated 700 years, between the rates of rock-fragment exposure by root throw and clast disintegration by chemical reduction. The estimated rate of rock-fragment reduction accounts for part of the fluvial sediment yields observed for forested subalpine areas of western North America. Copyright (c) 2005 John Wiley \& Sons, Ltd.
\end{abstract}

Keywords: root throw; bioturbation; rock-fragment veneer; sediment yield; pit/mound complex; hillslope stability

\section{Introduction}

Rock veneers, or rock-fragment veneers, are thin accumulations of rock clasts that partially or fully cover a surface or hillslope. The concentrations of generally gravel- or cobble-sized rock fragments develop by a variety of processes, all of which increase slope stability by protecting underlying fine sediment from erosion. Rock veneers typically extend no deeper than one or two clast thicknesses, thereby distinguishing them from thicker rock accumulations such as talus or coarse channel sediment. As applied herein, slope stability implies a condition of approximate adjustment whereby a slope is a surface of transportation, having neither removal nor change in storage of measurable amounts of sediment.

Hillslopes are partially or fully veneered with rock fragments in many parts of the world, and soil disturbance owing to root throw by toppling of trees is one process leading to rock-fragment veneers. Resistant rock fragments affect hydrologic and geomorphic processes in complex ways depending on whether the rock fragments rest on the surface or are within the soil matrix and profile (Poesen et al., 1994). Previous research concerning rock veneers focused on physical processes; a summary of this research documented the range of conditions under which those processes operate to produce and maximize rock veneers (Toy and Osterkamp, 1999). In general terms, there are two stages in the development of rock-fragment veneers. First, coarse-textured clasts are concentrated at and near the surface by freeze/thaw or wetting/drying processes (Cooke et al., 1993; Dohrenwend, 1987), accumulation of aeolian sediment beneath clasts (McFadden et al., 1987), or deposition of colluvium, mass-movement debris, or glacial till (Mills, 1981; Dohrenwend, 1987; Whitney and Harrington, 1993). During a second, possibly concurrent, stage, erosion by water or wind removes fine-textured material from the hillslope (Bryan, 1940; Cooke et al., 1993; Dohrenwend, 1987; Abrahams et al., 1985; Osterkamp and Toy, 1994) and the clasts may then be rearranged into a rock mosaic by sheet flooding (Williams and Zimbelman, 1994). 
Complete or extensive rock-fragment veneers, which have been termed desert pavement, stony mantle, hammada or reg (Cooke et al., 1993), are common on immature, or poorly developed, soils of arid and semiarid environments. They develop on hillslopes where, initially, an influx of rock fragments exceeds the outflux, resulting in accumulation. When the long-term rates of influx and outflux become equal, a condition of approximate equilibrium and hillslope stability may be established. If, however, the rate at which rock fragments are supplied to a hillslope is slower than the rate at which they are reduced through weathering processes, or if the influx rate is less than the outflux rate, accumulation of rock fragments is inadequate to result in a complete veneer.

Studies in the United States have demonstrated that processes of rock veneering occur in both dry and moist environments. Bryan (1940) discussed the 'gully gravure' process sequence by which rock veneers develop in forests of New Mexico and North Carolina. Hack and Goodlett (1960) described thin mantles of loose rock debris on hillslopes in the Appalachian Mountains of Virginia and the increase in the size of the debris as hillslope length and drainage area increase. Mills (1981) examined accumulations of boulders on the floors of hollows and the retreat of mountain slopes by means of a process similar to gully gravure in a forested part of Virginia, southwest of the Hack and Goodlett (1960) study area. In periglacial climates rock veneers may form by solifluction, soil creep, or clast emplacement by deformation of interstitial ice (rock glaciers), whereas large amounts of rock debris may accumulate as scree slopes or blockfields (felsenmeer) owing to frost action, root wedging, and related processes of mass wasting. Various types of bioturbation, such as tunnelling by pocket gophers and other burrowing animals, may lead to rock veneering in a wide range of environments (Cox and Hunt, 1990). A comprehensive review of the effect of bioturbation on sediment transport, especially by root growth and root throw, was provided by Gabet et al. (2003).

Numerous investigators have examined relations among processes and landform surfaces (e.g. Melton, 1965; Denny, 1967; Whitney and Harrington, 1993; Williams and Zimbelman, 1994; Wells et al., 1995). Most surface veneers of rock fragments protect underlying soil particles from detachment and downslope transport by water and thereby increase slope stability (e.g. Cooke et al., 1993; Simanton et al., 1994). Although the process-sets that lead to complete or partial rock veneers differ with environment and topographic position, the resulting geomorphic surfaces typically are similar. Thus, several process-sets are convergent, causing landform stability that is dependent not on the physical or biological processes by which it developed but on the armouring and soil protection provided by the rock fragments.

For the purposes of this paper, root throw is an event of bioturbation in which soil and rock are elevated to or above the surface by the fall of a tree and the rotation and exposure of its root ball. Tree toppling is the general cause of tree mortality by which land-surface disturbance occurs owing to the failure of a tree at or below the land surface, whereas tree throw is viewed as synonymous with root throw but is not used here as the term is less specific.

It is proposed herein that bioturbation by root throw in alpine and subalpine conifer forests on cool upland slopes combines with physical processes to cause the enrichment of rock clasts at the surface. A primary purpose was to determine whether root throw, followed by winnowing of fines, is an effective biophysical process that leads to a surface concentration of rock fragments. Specifically, the goals of this investigation were to determine: (1) whether the frequency of root throw, integrated over time and area, accounts for a partial rock veneer of hillslopes at the watershed scale; (2) whether rates of root throw, and thus rock veneering, vary with surface geology; (3) whether a balance occurs between the rate at which rock fragments are concentrated at the surface and the rate at which the clasts are reduced by chemical weathering; and (4) whether accepted rates of sediment yield for mountainous areas of western North America can be explained in terms of processes of rock veneering a forested site of southern Colorado, USA.

The determination of the rates, controls and results of root throw and associated processes of rock veneering at the Colorado site leads to an improved ability to characterize forest dynamics in semiarid, subalpine settings. Mountainous areas typically are drained by high-gradient streams that usually transport little suspended sediment. When widespread tree mortality occurs, due to wind, fire, disease or logging, fluvial sediment loads may increase dramatically. Practical elements of this study, therefore, are to identify the effect that root-throw bioturbation has (1) on landscape stability due to rock veneering, and (2) on landscape instability due to accelerated soil loss. This knowledge may provide a basis for evaluating other natural disturbances and the effects of forest-management practices.

\section{Site Characteristics}

The study was conducted along a 20-m wide, 500-m long transect in a subalpine (montane) setting of southern Colorado dominated by pines (Pinus ponderosa and P. contorta), Douglas fir (Pseudotsuga menziesii), and aspen (Populus tremuloides). The site, about $15 \mathrm{~km}$ south of Westcliffe, Colorado, USA (Figure 1), was selected following observations suggesting that (1) uprooting was a typical cause of tree mortality in forests uncut through most or all of the 20th century, and (2) uprooting typically increases in frequency as second-growth forest matures. The transect is mostly on private land in the NW quarter of section 1, township 24 south, range 73 west, Custer County, excepting the 


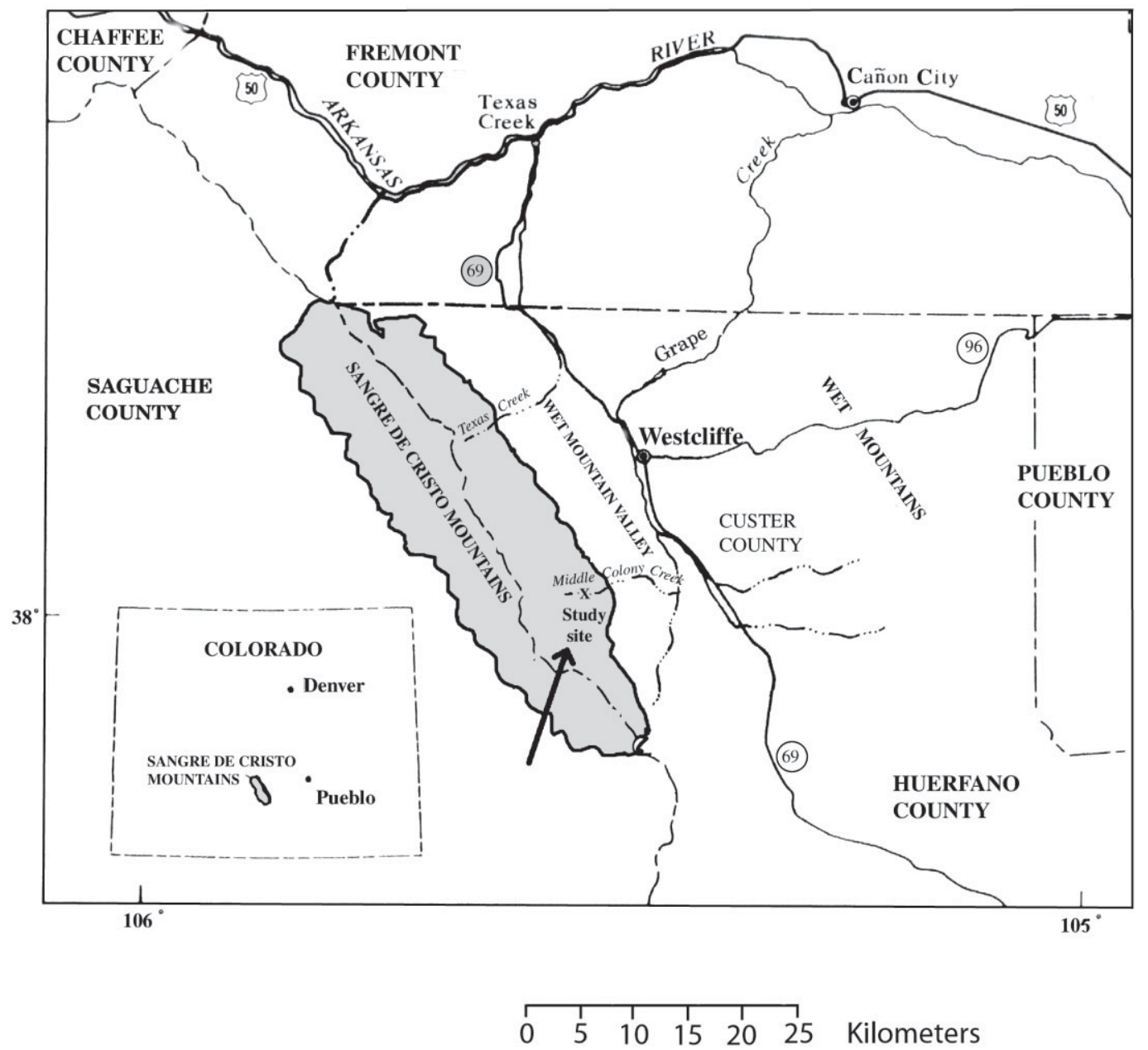

Figure I. Map of a portion of south-central Colorado, showing Westcliffe, the Sangre de Cristo Mountains (shaded), Middle Colony Creek and other streams of the area, and the location of the field study.

northernmost $5 \mathrm{~m}$, which is in the San Isabel National Forest. Records from the National Climatic Data Center indicate that annual precipitation at Westcliffe (elevation $2395 \mathrm{~m}$ ) since 1931 has averaged $425 \mathrm{~mm}$, two-thirds of which fell in April to September; much of the precipitation was as spring snowfall. Based on snow surveys and informal summer rain-gauge records, precipitation at the study transect is typically greater than in Westcliffe by an unknown amount. Average monthly temperatures during the period 1961 to 1990 ranged from $-5 \cdot 3{ }^{\circ} \mathrm{C}$ in January to $17 \cdot 3{ }^{\circ} \mathrm{C}$ in July.

Elevations along the transect range from about 2910 to $2925 \mathrm{~m}$; the lowest elevations along the transect occur between 137 and $270 \mathrm{~m}$, where the substrate is till of the Middle Colony Creek Valley consisting of gravel, cobbles and boulders, with interstitial fines. The till appears fresh, with weathering rinds rarely as thick as $2 \mathrm{~mm}$, and is inferred to be of late-Pinedale age (MacNish, 1966), about 12000 years BP. Protalus ramparts and rock glaciers in the vicinity of the transect are interpreted to be Temple Lakes in age, about 9000 years BP. North of this transect interval, beds of sandstone and conglomerate of the Sangre de Cristo Formation are generally mantled by up to $2 \mathrm{~m}$ of colluvial sand and silt that appear to have been deposited following land disturbance by upslope logging activity in the 1930s or earlier. South of the till, the Sangre de Cristo Formation is generally overlain by less than $1 \mathrm{~m}$ of residual weathering products and in many places bedrock is exposed. Trees in areas of colluvium and thinly covered bedrock are mostly mixed conifers, whereas both conifers (mostly Douglas fir) and aspen are common on the glacial deposits (Table I).

Trees at the Westcliffe site, and at similar sites of east-facing slopes of the Rocky Mountains, are susceptible to uprooting and snapping by high-velocity chinook winds, the regional name for vertical, cyclonic-induced, foehn winds. These winds typically occur in the winter and result from the downslope movement of relatively warm, dry air 
W. R. Osterkamp, T. J. Toy and M. T. Lenart

Table I. Conditions and characteristics of pit/mound complexes within the study transect, Westcliffe, Colorado

\begin{tabular}{|c|c|c|c|c|c|c|c|c|c|c|c|}
\hline No. & $\begin{array}{l}\text { Transect } \\
\text { position } \\
\text { (m) }\end{array}$ & $\begin{array}{c}\text { Pit } \\
\text { volume } \\
\left(\mathrm{m}^{3}\right)\end{array}$ & $\begin{array}{l}\text { Area } \\
\left(m^{2}\right)\end{array}$ & Geology & Forest type & $\begin{array}{l}\text { No. } \\
\text { clasts }\end{array}$ & $\begin{array}{l}\text { Mean clast } \\
\text { length }(\mathrm{m})\end{array}$ & $\begin{array}{l}\text { Mean clast } \\
\text { width }(\mathrm{m})\end{array}$ & $\begin{array}{l}\text { Mean clast } \\
\text { thickness } \\
(\mathrm{m})\end{array}$ & Tree species & $\begin{array}{l}\text { Decay } \\
\text { class }\end{array}$ \\
\hline । & 4 & $1 \cdot 8$ & $9 \cdot 1$ & Colluvium & Mixed conifer & & & & & Douglas fir & 3 \\
\hline 2 & 12 & 1.9 & $4 \cdot 5$ & Colluvium & Mixed conifer & 5 & 0.042 & 0.034 & 0.014 & Douglas fir & I \\
\hline 3 & 20 & & $4 \cdot 5$ & Colluvium & Mixed conifer & & & & & Ponderosa pine & 4 \\
\hline 4 & 28 & 0.2 & $3 \cdot 1$ & Colluvium & Mixed conifer & 5 & 0.164 & 0.094 & 0.052 & Douglas fir & 2 \\
\hline 5 & 66 & 0.4 & $3 \cdot 1$ & Colluvium & Mixed conifer & & & & & Ponderosa pine & 4 \\
\hline 6 & 104 & & $|\cdot|$ & Colluvium & Mixed conifer & & & & & Ponderosa pine & 4 \\
\hline 7 & 105 & 0.5 & $2 \cdot 5$ & Colluvium & Mixed conifer & 18 & 0.096 & 0.068 & 0.031 & & I \\
\hline 8 & 113 & $0 \cdot 2$ & $|\cdot|$ & Colluvium & Mixed conifer & 12 & 0.079 & 0.054 & 0.031 & Douglas fir & । \\
\hline 9 & 114 & $0 \cdot 3$ & $2 \cdot 5$ & Colluvium & Mixed conifer & & & & & Douglas fir & I \\
\hline 10 & 120 & $10 \cdot 0$ & $13 \cdot 8$ & Colluvium & Mixed conifer & & & & & Ponderosa pine & 4 \\
\hline 11 & 131 & & 1.5 & Colluvium & Mixed conifer & & & & & Douglas fir & 4 \\
\hline 12 & 132 & & 0.5 & Colluvium & Mixed conifer & & & & & Douglas fir & 4 \\
\hline 13 & 132 & & $|\cdot|$ & Colluvium & Mixed conifer & & & & & & 5 \\
\hline 14 & 160 & $0 \cdot 2$ & $1 \cdot 5$ & Till & Conifer/aspen & & & & & Aspen & 3 \\
\hline 15 & 170 & & $3 \cdot 1$ & Till & Conifer/aspen & & & & & Douglas fir & 3 \\
\hline 16 & 179 & 0.3 & $2 \cdot 0$ & Till & Conifer/aspen & & & & & Aspen & 2 \\
\hline 17 & 182 & & $|\cdot|$ & Till & Conifer/aspen & & & & & & 5 \\
\hline 18 & 188 & 0.1 & 0.8 & Till & Conifer/aspen & & & & & Douglas fir & 2 \\
\hline 19 & 190 & $0 \cdot 3$ & $2 \cdot 0$ & Till & Conifer/aspen & & & & & Douglas fir & । \\
\hline 20 & 195 & 0.0 & 0.8 & Till & Conifer/aspen & & & & & Douglas fir & 3 \\
\hline 21 & 196 & 0.0 & 0.8 & Till & Conifer/aspen & & & & & Douglas fir & 2 \\
\hline 22 & 211 & & $3 \cdot 1$ & Till & Conifer/aspen & & & & & Ponderosa pine & 4 \\
\hline 23 & 212 & $0 \cdot 3$ & $2 \cdot 5$ & Till & Conifer/aspen & & & & & Douglas fir & 2 \\
\hline 24 & 220 & & $|\cdot|$ & Till & Conifer/aspen & & & & & Douglas fir & 4 \\
\hline 25 & 225 & & 0.5 & Till & Conifer/aspen & & & & & Aspen & 2 \\
\hline 26 & 229 & & 0.5 & Till & Conifer/aspen & & & & & & $5+$ \\
\hline 27 & 235 & $0 \cdot 1$ & $2 \cdot 0$ & Till & Conifer/aspen & & & & & Aspen & 3 \\
\hline 28 & 237 & & $1 \cdot 5$ & Till & Conifer/aspen & & & & & & 4 \\
\hline 29 & 238 & & $|\cdot|$ & Till & Conifer/aspen & & & & & Lodgepole pine & 3 \\
\hline 30 & 240 & 0.1 & $2 \cdot 0$ & Till & Conifer/aspen & 37 & 0.152 & $0 \cdot 108$ & 0.058 & Douglas fir & 3 \\
\hline 31 & 240 & $0 \cdot 2$ & $2 \cdot 5$ & Till & Conifer/aspen & & & & & Lodgepole pine & 3 \\
\hline 32 & 253 & $0 \cdot 0$ & $|\cdot|$ & Till & Conifer/aspen & & & & & Douglas fir & 2 \\
\hline 33 & 265 & & $2 \cdot 0$ & Till & Conifer/aspen & & & & & & $5+$ \\
\hline 34 & 267 & $1 \cdot 4$ & $7 \cdot 1$ & Till & Conifer/aspen & & & & & Lodgepole pine & 3 \\
\hline 35 & 270 & 0.9 & $5 \cdot 3$ & Till & Conifer/aspen & 18 & 0.289 & 0.192 & 0.103 & Douglas fir & 4 \\
\hline 36 & 275 & $|\cdot|$ & $8 \cdot 0$ & Bedrock & Mixed conifer & & & & & Lodgepole pine & 4 \\
\hline 37 & 286 & $0 \cdot 3$ & $3 \cdot 1$ & Bedrock & Mixed conifer & & & & & & $5+$ \\
\hline 38 & 291 & 0.1 & $|\cdot|$ & Bedrock & Mixed conifer & & & & & Lodgepole pine & 3 \\
\hline 39 & 297 & $3 \cdot 2$ & $8 \cdot 0$ & Bedrock & Mixed conifer & 22 & 0.311 & 0.190 & 0.114 & & 2 \\
\hline 40 & 306 & $0 \cdot 2$ & $1 \cdot 5$ & Bedrock & Mixed conifer & & & & & Douglas fir & 3 \\
\hline 41 & 309 & & $2 \cdot 0$ & Bedrock & Mixed conifer & & & & & & 5 \\
\hline 42 & 319 & & 1.5 & Bedrock & Mixed conifer & & & & & & 4 \\
\hline 43 & 320 & & $3 \cdot 8$ & Bedrock & Mixed conifer & & & & & Douglas fir & 3 \\
\hline 44 & 338 & $0 \cdot 2$ & $3 \cdot 8$ & Bedrock & Mixed conifer & 27 & 0.182 & 0.110 & 0.072 & Douglas fir & 3 \\
\hline 45 & 338 & $3 \cdot 4$ & $5 \cdot 3$ & Bedrock & Mixed conifer & 38 & 0.166 & 0.110 & 0.059 & Ponderosa pine & I \\
\hline 46 & 340 & 0.5 & $3 \cdot 8$ & Bedrock & Mixed conifer & & & & & Douglas fir & 2 \\
\hline 47 & 341 & $2 \cdot 8$ & $7 \cdot 1$ & Bedrock & Mixed conifer & & & & & Douglas fir & 2 \\
\hline 48 & 342 & & $|\cdot|$ & Bedrock & Mixed conifer & & & & & Subalpine fir & 2 \\
\hline 49 & 344 & $0 \cdot 1$ & $|\cdot|$ & Bedrock & Mixed conifer & & & & & Douglas fir & 3 \\
\hline 50 & 344 & 0.1 & 1.5 & Bedrock & Mixed conifer & & & & & Douglas fir & 2 \\
\hline 51 & 353 & & $|\cdot|$ & Bedrock & Mixed conifer & & & & & Douglas fir & 4 \\
\hline 52 & 369 & $0 \cdot 1$ & 0.8 & Bedrock & Mixed conifer & & & & & Lodgepole pine & 2 \\
\hline 53 & 382 & 0.1 & $|\cdot|$ & Bedrock & Lodgepole pine & 14 & $0 \cdot 102$ & 0.059 & 0.034 & Lodgepole pine & 3 \\
\hline 54 & 383 & & $2 \cdot 0$ & Bedrock & Lodgepole pine & & & & & & $5+$ \\
\hline
\end{tabular}

(continued overleaf) 
Table I. (continued)

\begin{tabular}{|c|c|c|c|c|c|c|c|c|c|c|c|}
\hline No. $\quad \begin{array}{r}\mathrm{T} \\
\mathrm{P}\end{array}$ & $\begin{array}{l}\text { Transect } \\
\text { position } \\
\text { (m) }\end{array}$ & $\begin{array}{c}\text { Pit } \\
\text { volume } \\
\left(\mathrm{m}^{3}\right)\end{array}$ & $\begin{array}{l}\text { Area } \\
\left(m^{2}\right)\end{array}$ & Geology & Forest type & $\begin{array}{l}\text { No. } \\
\text { clasts }\end{array}$ & $\begin{array}{l}\text { Mean clast } \\
\text { length }(m)\end{array}$ & $\begin{array}{l}\text { Mean clast } \\
\text { width }(m)\end{array}$ & $\begin{array}{c}\text { Mean clast } \\
\text { thickness } \\
(\mathrm{m})\end{array}$ & Tree species & $\begin{array}{c}\text { Decay } \\
\text { class }\end{array}$ \\
\hline 55 & 409 & & $0 \cdot 8$ & Bedrock & Lodgepole pine & & & & & & 4 \\
\hline 56 & 411 & $0 \cdot 2$ & $|\cdot|$ & Bedrock & Lodgepole pine & & & & & Lodgepole pine & 3 \\
\hline 57 & 420 & & $3 \cdot 1$ & Bedrock & Lodgepole pine & & & & & & 5 \\
\hline 58 & 421 & 0.1 & $|\cdot|$ & Bedrock & Lodgepole pine & & & & & & 5 \\
\hline 59 & 423 & 0.5 & $1 \cdot 5$ & Bedrock & Lodgepole pine & & & & & Lodgepole pine & 3 \\
\hline 60 & 425 & 0.2 & $2 \cdot 0$ & Bedrock & Lodgepole pine & 7 & 0.299 & 0.209 & 0.131 & Lodgepole pine & 3 \\
\hline 61 & 426 & & $0 \cdot 8$ & Bedrock & Lodgepole pine & & & & & & 5 \\
\hline 62 & 440 & 0.0 & $0 \cdot 8$ & Bedrock & Lodgepole pine & & & & & Lodgepole pine & 2 \\
\hline 63 & 445 & & $3 \cdot 8$ & Bedrock & Lodgepole pine & & & & & & 5 \\
\hline 64 & 450 & $0 \cdot 1$ & 0.5 & Bedrock & Lodgepole pine & & & & & Ponderosa pine & 4 \\
\hline 65 & 455 & & $2 \cdot 5$ & Bedrock & Lodgepole pine & & & & & & $5+$ \\
\hline 66 & 463 & 0.5 & $3 \cdot 8$ & Bedrock & Lodgepole pine & 80 & 0.158 & 0.102 & 0.055 & Lodgepole pine & 2 \\
\hline 67 & 466 & 0.1 & $|\cdot|$ & Bedrock & Lodgepole pine & 25 & 0.099 & 0.066 & 0.043 & Lodgepole pine & 2 \\
\hline 68 & 474 & & 1.5 & Bedrock & Lodgepole pine & & & & & & $5+$ \\
\hline 69 & 474 & & $3 \cdot 1$ & Bedrock & Lodgepole pine & & & & & & $5+$ \\
\hline 70 & 476 & $0 \cdot 2$ & $2 \cdot 5$ & Bedrock & Mixed conifer & & & & & Ponderosa pine & 4 \\
\hline 71 & 487 & 0.2 & $1 \cdot 5$ & Bedrock & Mixed conifer & 49 & 0.096 & 0.066 & 0.032 & Douglas fir & 2 \\
\hline 72 & 492 & $0 \cdot 0$ & 0.3 & Bedrock & Mixed conifer & 13 & 0.067 & 0.048 & 0.029 & Douglas fir & 2 \\
\hline 73 & 498 & 0.1 & $|\cdot|$ & Bedrock & Mixed conifer & & & & & Lodgepole pine & 2 \\
\hline Total & & $\begin{array}{c}33 \cdot 6 \\
n=46\end{array}$ & $\begin{array}{l}183.4 \\
n=73\end{array}$ & & & & $\begin{array}{l}2 \cdot 302 \\
n=15\end{array}$ & $\begin{array}{l}1.510 \\
n=15\end{array}$ & $\begin{array}{l}0.858 \\
n=15\end{array}$ & & \\
\hline Average & & 0.7 & $2 \cdot 5$ & & & & 0.153 & 0.101 & 0.057 & & \\
\hline
\end{tabular}

(Trewartha, 1954; Neiburger et al., 1973). Chinook winds often are especially strong in the valleys of east-flowing streams, such as that of Middle Colony Creek at the Westcliffe site (Figure 1), where damage due to the toppling of trees can be pronounced.

Systematic logging (on private land) along the northern third of the transect ceased in the late 1930s (McConnell, 1988) and there was only limited logging during the 20th century along the southern $360 \mathrm{~m}$ of the transect (interval of 140 to $500 \mathrm{~m}$ ). The forest along the transect from $0 \mathrm{~m}$ to $370 \mathrm{~m}$ presently consists of mixed conifers and aspen. Beyond $370 \mathrm{~m}$, however, trees are mostly lodgepole pines that were generally too small for harvesting, although treering dating shows that in the 1930s they were up to 90 years in age. The dominance of lodgepole pine in this part of the transect may reflect fire (Weber, 1976), presumably in the mid-1800s. The transect intersects roads between 45 and $50 \mathrm{~m}$ and 100 and $102 \mathrm{~m}$ and crosses Middle Colony Creek between 143 and $145 \mathrm{~m}$. At least one fire, in about 1930, apparently restricted to the understorey, probably killed some trees along the 270 to $500 \mathrm{~m}$ transect interval (McConnell, 1988). Evidence of fire of unestablished date also occurs in the 100 to $120 \mathrm{~m}$ interval.

The elevation of tree line in the Middle Colony Creek Basin presently averages about $3350 \mathrm{~m}$. Based on the study by Short and Elias (1987) at the Mary Jane site in central Colorado, tree line in the Middle Colony Creek Basin during late-Pinedale time may have been 800 to $900 \mathrm{~m}$ lower than at present, or about $420 \mathrm{~m}$ lower than the elevation of the transect of the present study. Late-Pleistocene deglaciation is poorly dated in Colorado, but several studies indicate that it likely occurred during a period of 14000 to 12000 years вP (Nelson et al., 1979; Legg and Baker, 1980; Short, 1985; Madole, 1986; Short and Elias, 1987). Assuming that cool, dry conditions persisted at least through Pinedale or Temple Lakes time, and that reforestation of trees sufficiently large to be uprooted did not occur during that time, it is concluded that late-Quaternary soil disturbance by uprooting of trees could not have begun earlier than 9000 to 10000 years ago.

\section{Field Investigations and Data Summary}

Within $10 \mathrm{~m}$ east or west of the $500 \mathrm{~m}$ north-to-south transect an inventory was conducted of all toppled trees exhibiting root throw $(n=73)$. Adjusting for $9 \mathrm{~m}$ of roads and the stream across the transect, the area inventoried was 
$9820 \mathrm{~m}^{2}$ and had a density of nearly 7440 toppled trees per square kilometre. Included in the inventory were surface depressions (pits) where decayed wood of trees was no longer evident, but oval or circular concentrations of rock fragments remained.

Although highly variable over short distances, rock fragments of thickness greater than $10 \mathrm{~mm}$, apparently unrelated to sites of recent root throw, provide surface cover of about 1.1 per cent in areas of colluvium, $7 \cdot 4$ per cent in till, and $10 \cdot 6$ per cent in bedrock. At root-throw sites of tree toppling, measured rock-fragment covers ranged from $10 \cdot 3$ to 100 per cent in areas of till and bedrock, but were less than 5 per cent at all root-throw sites on colluvium. These percentages suggest that surface geology exerts a distinct influence on the amount of rock fragments available for translocation to the surface and the rates at which exposed rock fragments weather and disintegrate.

Using standard dendrochronologic techniques, including cross-dating, the times of tree death were approximated and the time elapsed from then to the survey was used as a proxy for the time since root throw (Lenart, 2003). These times were related to the degree of deterioration evident in the tree bole. Five decay classes, modified from categories developed by Arthur and Fahey (1990), Torres (1994) and Brown et al. (1998), are as follows.

1. Leaves, either brown or green, remain on attached limbs.

2. Bark of bole varies from intact to significant loss; partial loss of branches.

3. Little or no bark remains on a generally round bole and bole decay ranges from apparent to pronounced; decayed wood may grade to duff.

4. Roots remain but elliptically shaped bole grades into decomposed wood.

5. Little structural integrity of the bole; all organic matter of tree grades into soil.

$5+$. Rock fragments concentrated, but organic evidence of tree on surface lacking.

The duration of decay for classes 1 and 2 is measured in weeks to years, for class 3 in years to decades, for class 4 in decades. The elapsed time since tree death for class 5 was presumed to be up to two centuries in this environment. Times since uprooting of trees in decay class 5 are similar to the maximum ages determined by Brown et al. (1998) using dendrochronologic analyses for decayed lodgepole pine logs in a subalpine forest of central Colorado. An endmember, 5+, to this series refers to sites of rock concentration, possibly in a circular or oval configuration, where a shallow depression persists representing the pit formed by root throw. Direct evidence of the fallen tree is generally lacking except possibly enriched soil carbon.

Table I, including distance along the transect of root-throw sites, summarizes data collected for the study described herein. Pit volumes, computed from measurements of mean pit dimensions at root-throw sites (not listed), place an upper limit (adjusted by estimates of pit refilling) on the rock mass translocated to the surface. Also listed are areas defined by pits and spalled rock fragments at pit/mound complexes, descriptors of surface geology and forest type, the number of rock fragments inventoried at selected root-throw sites, averaged dimensions of rock fragments exposed at selected pit/mound complexes, species of uprooted tree at a site, if identifiable, and the assigned decay class of the tree. Most pit/mound complexes were elliptical in plan view, but to estimate area simply, the widths and lengths were averaged and the results were divided by two to approximate the radius of a circle (Table I).

Seventy-three sites of uprooted trees, 46 of which retained measurable pit dimensions, were inventoried along the $20 \mathrm{~m}$ wide $500 \mathrm{~m}$ transect (Table I). Ten additional sites of apparent root throw lacked wood from the fallen tree, but soil and rock-fragment conditions at the sites appeared sufficiently fresh that a conservative age of 200 years for tree toppling at these sites was assigned. The mean area of the 73 inventoried sites, including the rocks that fell from the toppled trees beyond the pit edges, was $2.5 \mathrm{~m}^{2}$. Thus, about $182 \mathrm{~m}^{2}$, or 1.9 per cent, of the transect area showed evidence of soil disturbance by root throw; this percentage of surface disturbance compares to published values as low as 0.09 per cent (Putz, 1983) and as high as 40 per cent (Denny and Goodlett, 1956). Computations based on geology and forest type (Table I) yield disturbed areas of 1.9 per cent for colluvium, 1.7 per cent for till, and 2.0 per cent for bedrock, and 1.9 per cent for mixed-conifer forest and 1.7 per cent for conifer/aspen forest. Although these differences lack statistical significance, a lower occurrence of root throw in areas of till geology and conifer/aspen forest than in a bedrock-dominated geology or a mixed-conifer forest may reflect either greater ease for tree-root growth, both vertically and laterally, in the unconsolidated till than in bedrock, or stability provided by communal root systems of aspen trees.

The number of clasts found and measured at a pit/mound complex is suggestive of the reservoir of rock fragments available in the soil for upward movement with a root ball. Measurement of clast lengths, widths and thicknesses permitted estimates of mean volumes of clasts that are exposed at a site of uprooting. The general direction (aspect) of land-surface slope at each pit/mound complex of the transect was recorded to indicate whether uprooting incidence varied between north- and south-facing slopes. Aspects are not provided in Table I because no systematic variation in uprooting incidence was identified. 


\section{Treefall, Root Throw and Rock Veneering}

Uprooting is a common cause of tree mortality in temperate forests, especially in northeastern, north-central, and subalpine areas of the United States. It is there that research on the effects of root throw has been most active (Schaetzl et al., 1989). Many trees with root or bole decay snap at or near ground level. Others, often large conifers and hardwoods with healthy roots and stems, fail (1) by root throw during high-intensity wind storms, (2) as a result of growth on thin soil capping near-surface bedrock or on moist soil of low cohesive strength, or (3) owing to the combined effects of the two. Because root throw generally refers to the toppling of a tree without severing all large roots near the bole, the process results in the upward pivoting of the root mass with soil and rock fragments (Figure 2). The upward and lateral movement of the root/soil/rock mass leaves a shallow depression, or a pit. In some areas of mature forest and low soil strength, pitting of the surface due to root throw may be spatially extensive (Lorimer, 1977; Brewer and Merritt, 1978; Schaetzl et al., 1989).

\section{Veneer development process}

Because root throw appears to be a principal process by which clasts are elevated to the surface, an assessment of root-throw frequency at the Westcliffe site is necessary to estimate a rock-fragment influx rate. If a rate of rockfragment removal, or outflux, also can be estimated, the degree of rock veneering and hillslope stability can be evaluated.

Following uprooting of a tree, some soil and rock fragments fall into the pit or a short distance adjacent to the pit. Much of the soil and rock lifted by the root ball, however, may remain attached to the mass, slaking off during subsequent years in response to rain-splash erosion, physical weathering, and root decay. The fine sediment that falls either returns to the pit or is subject to downslope transport by raindrop impact, overland flow, and wind entrainment. The coarse rock fragments may remain as a relatively immobile lag deposit contributing to the rock veneer. These rock fragments are reduced in size and weight during following years, depending on lithologic characteristics and sitespecific conditions of chemical and physical weathering.

Typically, some of the rock and soil elevated by root throw eventually falls forward from the root ball beyond the pit edge, yielding a rock veneer of greater area than that defined by the pit. The width and length of the apparent area of disturbance (as indicated by the oval extent of rock fragments at both recent and older sites of root throw) were measured and the area within an assumed circle was computed. Where a pit was largely refilled with sediment and the remains of the uprooted tree were no longer evident, only measurement of the area of disturbance was possible.

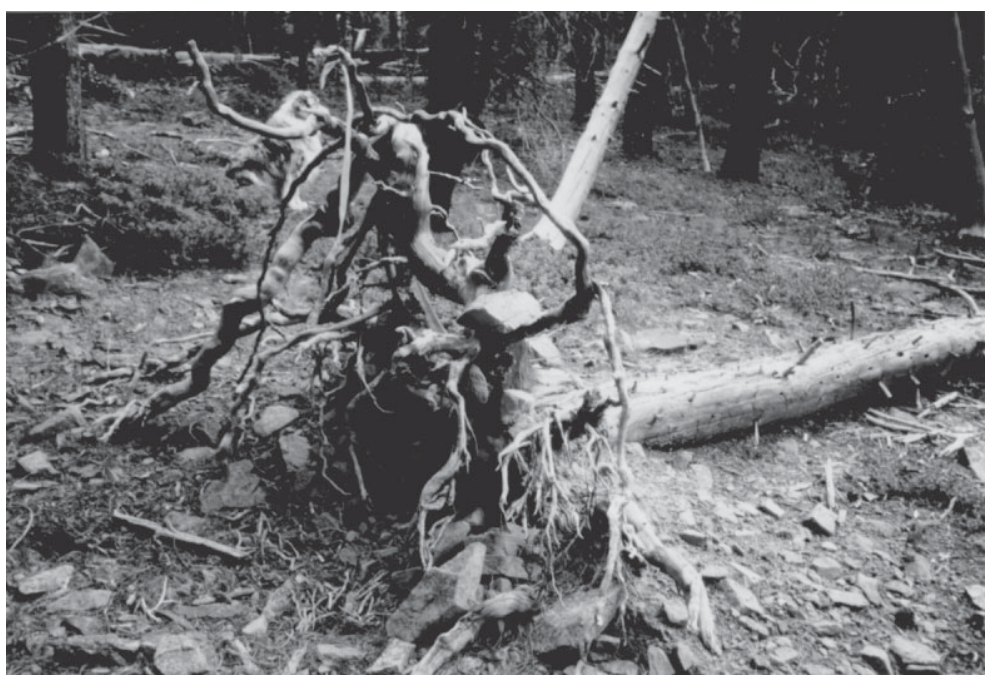

Figure 2. Photograph of pit/mound complex 66 at metre 463, in the bedrock section of the transect; the tree is a lodgepole pine, decay class 2 , and the sandstone fragments have a mean thickness of $0.055 \mathrm{~m}$ (Table I). 
The earliest documented time of death of an uprooted tree along the transect was about 1924 , nearly 80 years before field investigations; the tree was judged representative of the transition between decay classes 3 and 4 . Several other fallen trees, however, were suggestive of classes 4 and 5 and may indicate up to 200 years of decay. Thus, during each of the past two centuries up to 0.95 per cent ( 1.9 per cent/2) of the landscape may have been disturbed by root throw; this estimate is regarded as conservative owing to the difficulty of identifying the extent of old disturbances and rockfragment deterioration with time. The fraction, $F$ (expressed as a percentage), of area disturbed after a specified number of years, assuming a disturbance rate, $p$, of 0.95 per cent per century and that sites of root throw are randomly susceptible to repeat disturbances, was computed by:

$$
F=1-(1-p)^{t}
$$

in which the exponent, $t$ (years), accounts for the probability of a site being disturbed more than once (R. H. Hawkins, University of Arizona, pers. comm., 2003). According to this relation, approximately 9, 38 and 61 per cent of the landscape would be disturbed each 1000-, 5000- and 10 000-year period. Owing to the relatively small number of pits inventoried in decay classes 5 and $5+(n=14)$, it is assumed that some pits more than a century old are not recognized. Accordingly, computations for decay classes 1 to 4 and a period of 100 years, indicate that about 15,55 and 80 per cent of the landscape would be disturbed by root throw in 1000, 5000 and 10000 years.

\section{Root-throw frequency}

The above estimates for a forest in southern Colorado suggest that a complete disturbance cycle, the time required to achieve nearly total disturbance of the surface, does not appear to have been feasible since post-Pleistocene reforestation in this area. The estimates differ from computed disturbance cycles by root throw of 3570 to 5000 years for a forested area of Michigan (Brewer and Merritt, 1978), 220 to 25000 years for various pine, fir, spruce, and mixed conifer/deciduous forests, also in Michigan (Whitney, 1986), 1730 years for forests of Illinois (Schaetzl et al., 1989), 1210 years for a fir/deciduous forest of Wisconsin (Canham and Loucks, 1984), 1150 years for a coniferous/deciduous forest of Maine (Lorimer, 1977), 100 to 280 years for a Nothofagus solandri forest of New Zealand (Wardle, 1970), and 1600 to 4500 years for a range of forest types affected by hurricane damage in Puerto Rico (Lenart, 2003).

The climates, growth rates and densities of trees, and soils examined during these studies, as well as the assumptions and computation methods used, are not consistent, are generally not the same as those used in this investigation, and thus are not directly comparable. They do suggest, however, that root-throw frequency is likely to be greater in forests of the moist midwestern United States (and New Zealand) than in alpine and subalpine forests of the semiarid western United States. This difference in root-throw frequency is explained in part by generally faster growth rates for trees in moist areas than in the drier subalpine areas of southern Colorado. Furthermore, because soils of the upper Midwest are generally finer grained and more mature than those of southern Colorado, root throw seems an unlikely process for significant rock veneering.

If past rates of root throw were similar to recent rates, if no rock weathering occurred, and if root throw did not occur repeatedly at the same sites, up to 90 per cent of the surface could have been rock-veneered by root throw during Holocene time. This estimate is based on the observation that only the part of the transect underlain by till, interval 137 to $270 \mathrm{~m}$, was glaciated, but that the entire transect was probably higher than tree line prior to 10000 years BP.

\section{Weathering of rock fragments}

Most estimates of rock-fragment veneering are not adjusted for clast breakdown. At the Westcliffe site most clasts are from loosely to moderately cemented beds of the Sangre de Cristo Formation and are susceptible to relatively rapid disintegration. Rates of sandstone disintegration in a cool semiarid climate are not well established, but an estimated range for a glaciated surface at Spitsbergen is 0.34 to $0.5 \mathrm{~mm} \mathrm{a}^{-1}$ (Rapp, 1960). Clast thicknesses at the Westcliffe site mostly are less than $100 \mathrm{~mm}$ (Table I). If sandstone clasts of that size, from the Sangre de Cristo Formation, were reduced only on exposed surfaces by $0.4 \mathrm{~mm} \mathrm{a}^{-1}$, a $100-\mathrm{mm}$ thick fragment would disintegrate within 250 years. Strongly cemented clasts would fail much more slowly. Although most sandstone clasts from the Sangre de Cristo Formation appear to weather at rates significantly less than $0.4 \mathrm{~mm} \mathrm{a}^{-1}$, these observations help explain why only partial rock veneers occur along the Westcliffe transect and why rock-fragment accumulations are rare where no evidence of decayed wood occurs. Measured reduction rates for other rock types (granite, greywacke, diabase, andesite and basalt) are much slower (Watanabe, 1990), indicating why rock-fragment veneers seem to be better developed and more persistent in other geologic settings than at the Westcliffe site. 


\section{Hillslope-stability model}

The balance between the rate of rock-fragment veneering and the wasting of sandstone clasts by chemical weathering at the Westcliffe site can be evaluated using a modification of a generalized hillslope-stability (equilibrium) model (Toy and Osterkamp, 1999) for the development of rock veneers:

$$
A=M L /\left(1-\mathrm{e}^{-L t}\right)
$$

At the Westcliffe site, initial post-Pleistocene conditions of no forest development or rock-fragment cover are inferred. With the beginning of root-throw processes, rock fragments move to the surface at rate $A$ (mass per unit area and time interval, $t$ ) and start to accumulate as a body of rock fragments, $M$ (mass), stored during a specified period of time. Reduction of rock fragments exposed at the surface by weathering begins, and increases in rate as the mass of the stored rock-fragment body increases. This loss of mass, $L$, is an outflux of rock fragments, is expressed as a fractional loss rate of $A$ to $M$, and thus has dimensions of $1 / t$. With time the accumulation of rock fragments becomes great enough that loss of mass by weathering balances the continuing introduction of rock fragments by root throw, stored rock mass no longer changes with time, a partial rock veneer is established, and the hillslope attains an approximate equilibrium. Where mass loss by removal or by weathering is rapid, as at the Westcliffe site, the influx rate of rock mass must be high to maintain a rock-fragment accumulation, and $L$ may approach its limiting value of 1.0 for surfaces without rock-fragment accumulation.

An exact solution for $L$ in equation 2 is not feasible when using estimated values for $A$ (the influx of rock mass) and $M$ (the accumulation of rock mass at the surface by root throw during a selected time increment). The equation can be evaluated effectively, however, by substituting reasonable approximations for $A$ and $M$, hence $L$, iteratively until computations yield consistent results when solved for $A$. By this approach, input values for $A$ were estimated as rates of rock-fragment exposure by root throw (in $\mathrm{t} \mathrm{km}^{-2}$ per century) and values for $M$ were estimated as mass of rock fragments (in $\mathrm{t} \mathrm{km}^{-2}$ ) in time $t$. Increments of time, $t$, were assigned lengths of 100 years.

To compute $L$, values of $A$ and $M$ were estimated using measured amounts of rock cover and the data of Table I for decay classes 1, 2 and 3. These classes (Table I) apply to periods up to 20 years, yielding a multiple of five to define a time period, $t$, of 100 years. The measured area of freshly formed soil-rock, pit/mound complexes (Table I) is about $106 \mathrm{~m}^{2}, 1 \cdot 1$ per cent of the transect area, and provides a rock cover estimated to be 90 per cent. The mean clast thickness for these complexes $(n=14)$ is $0.057 \mathrm{~m}$, giving a rock-fragment volume of $5.44 \mathrm{~m}^{3}$ for the rock-cover area of $95 \mathrm{~m}^{2}$. Assuming a dry bulk density of $2.0 \mathrm{~g} \mathrm{~cm}^{-3}$ (a value typical for moderately indurated sandstone), the rate of mass influx, $A$, within the entire transect area is $10 \cdot 9 \mathrm{t}$ per century, or slightly more than $11 \mathrm{t} \mathrm{km}^{-2} \mathrm{a}^{-1}$.

An estimate of the accumulated rock mass, $M$, is based on a rock cover of 0.95 per cent, or $93.3 \mathrm{~m}^{2}$, for the transect area, plus a total area of $77.6 \mathrm{~m}^{2}$ with a 70 per cent rock cover for pit/mound complexes of decay classes 4,5 and $5+(n=30)$. Assuming again a dry bulk density of $2.0 \mathrm{~g} \mathrm{~cm}^{-3}$ for the rock fragments, a rock mass of $12 \cdot 1 \mathrm{t}$ is computed for the transect area, or $1230 \mathrm{t} \mathrm{km}^{-2}$. Thus, the estimated value of $L$ is $0 \cdot 9$. Solving Equation 2 for rock mass, $M$, yields $729 \mathrm{t} \mathrm{km}^{-2}$ after 100 years, and an equilibrium between influx of rock fragments by root throw and loss of mass by rock weathering is approached after about 700 years (Figure 3). It is concluded from these estimations that a period of roughly 700 years is needed to effect disintegration at the exposed surfaces of $100 \mathrm{~mm}$ thick clasts and thus attain mass balance. The rate of chemical degradation of exposed clasts from the Sangre de Cristo Formation, therefore, may be closer to $0.14 \mathrm{~mm} \mathrm{a}^{-1}$ than the value of $0.4 \mathrm{~mm} \mathrm{a}^{-1}$ initially considered from the estimates of Rapp (1960).

\section{Sediment yield}

The computed rate at which the rock-fragment component of soil is brought to the surface by root throw, $A$, approaches the estimated long-term rate at which sediment enters the fluvial system if processes of soil formation and soil loss result in an approximate equilibrium - that is, mean soil thickness is not changing. Sediment-yield data are not available for Middle Colony Creek and the Westcliffe site, but measured sediment yields for soil-erosion plots and completely forested areas of less than $5.2 \mathrm{~km}^{2}$ in the western United States $(n=80)$ ranged from 2.2 to $116 \mathrm{t} \mathrm{km}^{-2} \mathrm{a}^{-1}$ and averaged about $16 \mathrm{t} \mathrm{km}^{-2} \mathrm{a}^{-1}$ (J. H. Patric, Forest Service, USDA, pers. comm., 1983; Patric et al., 1984). Soils at the Westcliffe site are thin and immature, suggesting that loss of sediment, mostly sand, from hillslopes of the area is in approximate balance with addition of sediment by weathering of the Sangre de Cristo Formation.

Sediment yields and sediment characteristics closely comparable to conditions of the Westcliffe site were described by Leaf (1970) for subalpine catchments in the Fraser Experimental Forest in central Colorado, west of Denver and about $200 \mathrm{~km}$ north of the Westcliffe site. The catchment areas of Deadhorse Creek $\left(2 \cdot 7 \mathrm{~km}^{2}\right)$, Lexen Creek $\left(1.2 \mathrm{~km}^{2}\right)$, 


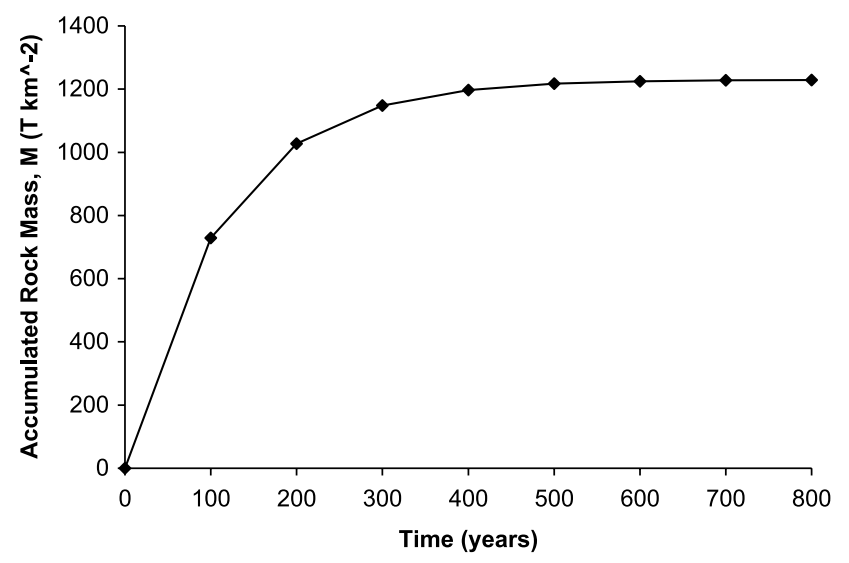

Figure 3. Graph showing the rate of accumulation of rock mass at the Westcliffe site by root throw but limited by clast breakdown due to weathering; the graph is based on an initial condition of no rock veneer and a value of $L$, the fractional loss of rock influx relative to rock accumulation, of 0.9 .

and Fool Creek $\left(2.9 \mathrm{~km}^{2}\right)$ are at elevations of about $2740 \mathrm{~m}$ and receive mean annual precipitation of about $670 \mathrm{~mm}$, two-thirds of which falls as snow. Sandy, permeable soils in the catchment areas have low silt/clay contents, and thus convey little direct runoff or sediment to stream channels. Drainage density is very low and the forest is predominantly lodgepole pine, fir and spruce. Tree fall was not acknowledged by Leaf (1970), but a dense surface litter, duff, was described as including rotting wood. Debris basins were used to trap and measure total sediment loads (trap efficiencies were regarded as high, with little loss due to through-flow of water and suspended sediment) of each stream during the period 1952 to 1966 . Results gave sediment yields of $3 \cdot 6,2 \cdot 5$, and $5 \cdot 3 \mathrm{t} \mathrm{km}^{-2} \mathrm{a}^{-1}$ (the last, for Fool Creek, being based on the last nine years of record following recovery from partial timber harvesting). Other rates of sediment flux for areas of root throw, converted to sediment yield using an assumed dry bulk density of $2 \cdot 0 \mathrm{~g} \mathrm{~cm}{ }^{-3}$, include $1.6 \mathrm{t} \mathrm{km}^{-2} \mathrm{a}^{-1}$, based on theoretical considerations and assumed pit dimensions for a deciduous forest by Gabet et al. (2003), and $1.9 \mathrm{t} \mathrm{km}^{-2} \mathrm{a}^{-1}$ for forested areas of the Clearwater River Basin, Washington, USA, by Reid (1981).

\section{Discussion}

The sediment yield potentially related to root-throw disturbance by this investigation, $11 \mathrm{t} \mathrm{km}^{-2} \mathrm{a}^{-1}$, is consistent with the findings of Patric and his colleagues but is higher than the measured yields of Leaf (1970). In addition, the inference that soils at the Westcliffe site, though poorly developed, are fully adjusted to weathering and erosion processes is compatible with the low value estimated for sediment yield and a relatively rapid rate of sandstone reduction. Although errors associated with these estimates reduce the confidence with which conclusions can be advanced, the comparisons suggest that root throw may be a primary process of soil disturbance by which sediment becomes available to enter the fluvial system at the Westcliffe site, and possibly at many other sites of similar climate and geology. If sediment yields of the watersheds studied by Leaf (1970) are indeed less than half of those at the Westcliffe site, a reasonable explanation might be that recent rates of sediment release by root throw near Westcliffe have been elevated due to forest-management practices of the last century, such as fire suppression, which have resulted in large, unstable trees. This possibility, if valid, suggests that processes of sediment movement may be in temporary disequilibrium.

The potential for rock veneering by root throw appears greatest where several biophysical conditions occur in combination. Among these characteristics are: (1) climatic and geologic conditions that yield weathering products low in clay but rich in near-surface clasts; (2) a rate of chemical weathering that is slow, allowing the accumulation and persistence of rock fragments; (3) precipitation, especially as snow and short-duration convective events, that is inadequate to generate sufficient runoff to transport rock fragments; (4) the frequent occurrence of high-velocity wind; (5) climatic and geologic conditions favouring tree species with shallow root systems; and (6) trees that attain sufficient size, height and root mass that when uprooting occurs the root balls are of adequate depth and girth to translocate the embedded coarse rock fragments to the surface.

Conditions at the Westcliffe site are favourable for bioturbation by root throw, but are less suitable for an accumulation of clasts sufficient to yield a rock veneer. Referring to the previously enumerated biophysical characteristics, 
those favouring bioturbation by root throw are weathering of bedrock to sandy soils deficient in fine particle sizes (1), strong seasonal winds (4), and a forest composed mostly of large, native trees with shallow root systems (5 and 6). Although the rate of chemical weathering (2) in this environment is slow, sandstone and conglomerate beds of the Sangre de Cristo Formation mostly lack sufficient resistance to prevent relatively rapid reduction to sand. Consequently, only a partial rock veneer has developed at the Westcliffe site.

The similarity in the rates of sediment release by rock-fragment disintegration and sediment transport by water, as reported by Leaf (1970) and Patric et al. (1984), among others, does not demonstrate cause and effect. If, however, the long-term rate of clast reduction were measurably greater than that of sand removal by fluvial processes, either the storage of sand and regolith thickness would increase, or downslope migration of sand would have to occur by other processes, such as by aeolian entrainment. Because soils at and downslope from the transect are thin and poorly developed, neither condition appears to apply. Rather, the relatively small supply of stored sediment suggests that, on a millennial time scale, as sand is released to the soil surface equivalent amounts leave the area by overland flow and related hillslope processes.

Drainage density (the summation of channel lengths within a unit area) is an indicator of infiltration capacity, susceptibility of soils to erosion, and, indirectly, the potential for rock veneering by root throw. A value of drainage density less than $8 \mathrm{~km} \mathrm{~km}^{-2}$ suggests that an area, such as a rock-veneered hillslope, has erosion-resistant conditions and low sediment yield, whereas values of $200 \mathrm{~km} \mathrm{~km}^{-2}$ and higher occur on highly erodible surfaces of high sediment yield (Strahler, 1957; Gregory and Gardiner, 1975). At the Westcliffe site, sandy, permeable soils of till and the Sangre de Cristo Formation possess high infiltration capacities, thereby minimizing the runoff available to move sediment from interfluves to sites of concentrated flow. This results in a very low drainage density of $1.9 \mathrm{~km} \mathrm{~km}^{-2}$ and a low rate of sediment yield. In comparison, Leaf (1966) reported drainage densities $\left(\mathrm{km} \mathrm{km}^{-2}\right)$ of 8.3 for Deadhorse Creek, 6.5 for Lexen Creek, and 4.8 for Fool Creek.

The low drainage-density value for the Westcliffe site indicates that runoff by processes of concentrated flow in rills and gullies transports little sediment to channels. Some silt and fine sand no doubt leave the Westcliffe site by aeolian transport, especially with chinook (foehn) winds, but most surfaces are protected by vegetation, rock or rock fragments, or duff, and are not susceptible to significant erosion or sediment sorting by aeolian processes. Evidence for other than small-scale, site-specific sediment movement by relatively rapid mass movements is lacking at the Westcliffe site, as is evidence for low-velocity mass movements such as soil creep and solifluction. It is concluded, therefore, that most of the sediment released by root throw and rock weathering passes to stream channels by low-energy, gravityinduced processes of freeze and thaw, various forms of bioturbation, and downslope movement of duff, snow, ice and meltwater. This explanation for how sediment may leave a subalpine slope is similar to that proposed in a study conducted in Potter County, Pennsylvania, USA. In a discussion of erosion induced by root throw, Denny and Goodlett (1956) conceptualized released sediment as migrating slowly downslope as a near-surface layer analogously to soil creep. At the Westcliffe site the set of processes may be similar to that of Potter County, not resulting in soil creep but in surface and near-surface disturbance and downslope movement of sediment particles.

In the Westcliffe study area, the climate is cool. Precipitation is relatively low in amount and rarely intense, with about one-third occurring as snow. These conditions, combined with elevations that approach $3000 \mathrm{~m}$ and result in low temperatures, inhibit rates of chemical weathering and ensure short-term exposure and persistence of rock fragments. Sandstone clasts derived from the Sangre de Cristo Formation, however, typically are poorly to moderately cemented and are readily reduced by freeze/thaw and wetting/drying processes at the surface. Near-surface beds of sandstone and conglomerate generally are thinly covered with immature soil, thereby limiting tree species to those not dependent on deep tap roots for water and stability. Immature soils support a mature mixed-conifer forest with a nearly full canopy but little understorey.

As discussed elsewhere, soils at the Westcliffe site are sand-rich and have low contents of clays and other diagenetic minerals. Unlike thin soils of many wetter, warmer areas, the sandy soils of the Westcliffe site are highly porous and permeable. Soils overlying beds of the Sangre de Cristo Formation generally grade from fine- to medium-grained sand near the surface, to sand and angular sandstone and conglomerate fragments above the bedrock surface, whereas soil formed on till is dominated by gravel, cobbles and boulders with interstitial sand and silt. Regardless of geology, the soils readily accept water, mostly as snowmelt, the result being meagre surface runoff and a near-absence of rills and gullies. Streamflow in Middle Colony Creek peaks during spring melting of snow, but is mostly, if not entirely, fed by ground-water inputs throughout the year. These characteristics, resulting in low sediment yield, are typical of subalpine catchment areas in Colorado and nearby areas of the western United States.

The deficiency of surface runoff and sediment entrainment is consistent with the transport-limited model for soil and hillslope development first advanced by Gilbert in 1877 and extended by Carson and Kirkby in 1972. The poor soil development of the area, however, is strongly indicative of a weathering-limited condition (Carson and Kirkby, 1972). Both models, of transport limitation and supply limitation, are expressed in terms of balance between the rate 
of release of sediment to the system and the rate at which sediment leaves the system. The apparent contradiction for the Westcliffe site and similar subalpine areas does not appear to reflect disequilibrium, but is the result of the opposing models being ill-defined for the Westcliffe area.

Weathering rates near Westcliffe are relatively slow owing to a semiarid climate and a seasonally snow-blanketed landscape. Meltwater, which rapidly infiltrates and re-emerges from shallow ground-water reservoirs as base-flowdominated discharge, rarely becomes concentrated in other than channels of perennial streamflow. Sediment yield is low and does not occur primarily by overland flow and rill, inter-rill or gully erosion, but by a variety of gravitational, physical-weathering, and biological processes. These controls cause (1) slow rates of weathering except at rock exposures, (2) thin soils, and (3) characteristics of a weathering-limited condition. Owing to the deficiency of overland flow and the potential for sediment transport, however, the Westcliffe site also exhibits features of transport limitation. Results of this investigation are inadequate to evaluate which, if either, model is more applicable. It does seem apparent, however, that the rates of both sediment release and sediment loss are very low, that sediment stored as soil is minimal, and that an approximate balance among them is in effect. Thus, soils at the Westcliffe site appear to maintain an equilibrium, as defined by Carson and Kirkby (1972), even though processes of root throw have not disturbed the entire transect area during Holocene time.

Rates of disturbance and rock-fragment accumulation estimated here may be applicable to other subalpine areas in the Rocky Mountains with similar physical and vegetation conditions, but may be unrepresentative of forests with different characteristics. Observations elsewhere, however, substantiate that the rock-veneering process described herein occurs in many other upland environments. Goodlett (1954) and Denny and Goodlett (1956) described pits, mounds and bioturbation caused by root throw on the moist, well vegetated slopes of Potter County, Pennsylvania. Although their approach may not be directly comparable to results of this investigation, conversion of their estimates (corrected, to account for a computational error) to sediment yield from bioturbation on the well protected slopes of Potter County gives $2 \cdot 0 \mathrm{t} \mathrm{km}^{-2} \mathrm{a}^{-1}$, about one-fifth of the $11 \mathrm{t} \mathrm{km}^{-2} \mathrm{a}^{-1}$ reported here for the drier, sandier Westcliffe site.

\section{Conclusions}

Rock veneers can be the result of several previously described sequences of physical processes, each leading to a concentration, if not a cover, of coarse rock fragments on hillslopes. Results of this study indicate that a complete surface-disturbance cycle by root throw was unlikely in the 9000 years since reforestation occurred at the Westcliffe site. The finding is consistent with observations of low sediment yields from otherwise undisturbed alpine and subalpine forests of the American West and with observations of only minor rock veneering in many other montane environments. Furthermore, reduction of rock fragments to sand at the Westcliffe site appears to be too rapid to permit the development of an extensive rock veneer.

Estimates of sediment yield attributable to root-throw processes in this investigation are limited to that portion of sediment yield resulting from the chemical breakdown of sandstone fragments. The estimates, therefore, are conservative because sand and finer sediment sizes that form mounds following tree toppling are not considered. Lenart (2003) estimated that 30 to 50 per cent of the soil and rock fragments elevated above the surface by root throw fall into the pit and do not contribute to sediment yield on a decadal time scale. Thus, the sediment leaving the Westcliffe site that results from root-throw bioturbation is inferred to comprise only part of the long-term sediment yield. Because sediment yields from relatively undisturbed forests of the western United States typically are low, the proportion, as opposed to the amount, contributed by root throw appears to be substantial.

Because rock veneers typically stabilize hillslope surfaces, they are products of hillslope evolution rather than causes of it. The development of rock veneering by tree toppling and root throw is similar in result to other veneering processes but differs by requiring a combination of physical and biological processes. Rock covers occur by different process-sequences and serve as examples of geomorphic convergence and landform equifinality. Furthermore, the development of rock veneers is an example of functional equifinality, whereby processes of geomorphic change tend to yield stable landforms that become increasingly resistant to further change. Rock veneers armour the surface from erosive forces and protect it from detachment and entrainment of underlying soil particles by raindrop impact and overland flow, and thereby stabilize hillslopes. At the Westcliffe site, processes leading to a stabilizing veneer are imperfectly operative and hence contribute only a partial protection.

Results of the study described herein suggest that mature trees at the Westcliffe site are susceptible to toppling and root throw, and that this type of bioturbation is one of the principal processes of landscape disturbance in this environment. The long-term rate of root throw at the Westcliffe site is sufficient to cause a partial rock veneer, but relatively rapid chemical weathering results in a balance between exposure and disintegration of the rock fragments. 
Unlike forest fire, timber harvesting, and other infrequent causes of tree mortality and soil disturbance, root-throw bioturbation, and sediment released by it, may account for much of the fluvial sediment regularly entrained by highgradient streams in this part of Colorado.

\section{References}

Abrahams AD, Parsons AJ, Hirch PJ. 1985. Hillslope gradient-particle relations: evidence for the formation of debris slopes by hydraulic processes in the Mohave Desert. Journal of Geology 86: 743-752.

Arthur MA, Fahey TJ. 1990. Mass and nutrient content of decaying boles in an Engelmann spruce-subalpine fir forest, Rocky Mountain National Park, Colorado. Canadian Journal of Forest Research 20: 730-737.

Brewer R, Merritt PG. 1978. Wind throw and tree replacement in a climax beech-maple forest. Oikos 30: 149-152.

Brown PM, Shepperd WD, Mata SA, McClain DL. 1998. Longevity of windthrown logs in a subalpine forest of central Colorado. Canadian Journal of Forest Research 28: 932-936.

Bryan K. 1940. Gully gravure - a method of slope retreat. Journal of Geomorphology 3: 89-107.

Canham CD, Loucks OL. 1984. Catastrophic windthrow in the presettlement forests of Wisconsin. Ecology 65: 803-809.

Carson MA, Kirkby MJ. 1972. Hillslope Form and Process. Cambridge University Press: London.

Cooke RU, Warren A, Goudie AS. 1993. Desert Geomorphology. ULC Press: London Cox GW, Hunt J. 1990. Nature and origin of stone stripes on the Columbia Plateau. Landscape Ecology 5(1): 53-64.

Denny CS. 1967. Fans and pediments. American Journal of Science 265: 81-105.

Denny CS, Goodlett JC. 1956. Microrelief resulting from fallen trees. In Surficial Geology and Geomorphology of Potter County, Pennsylvania, Denney CS (ed.). US Geological Survey Professional Paper 288. USGS: Washington DC; 59-66.

Dohrenwend JC. 1987. Basin and Range. In Geomorphic Systems of North America, Graf WL (ed.). Centennial Special Volume 2. Geological Society of America: Boulder, Colorado; 303-342.

Gabet EJ, Reichman OJ, Seabloom EW. 2003. The effects of bioturbation on soil processes and sediment transport. Annual Review of earth and Planetary Sciences 31: 249-273.

Gilbert GK. 1877. The Geology of the Henry Mountains. United States Geographical and Geological Survey: Washington.

Goodlett JC. 1954. Vegetation Adjacent to the Border of the Wisconsin Drift in Potter County, Pennsylvania. Forest Bulletin 25. Harvard: Petersham, Massachusetts.

Gregory KJ, Gardiner V. 1975. Drainage density and climate. Zeitschrift für Geomorphologie 19: 287-298.

Hack JT, Goodlett JC. 1960. Geomorphology and Forest Ecology of a Mountain Region in the Central Appalachians. US Geological Survey Professional Paper 347. USGS: Washington DC.

Leaf CF. 1966. Sediment Yields from High Mountain Watersheds, Central Colorado. Research Paper RM-23. US Forest Service: Fort Collins, Colorado.

Leaf CF. 1970. Sediment yields from central Colorado snow zone. ASCE Journal of the Hydraulics Division 96(HY1): 87-93.

Legg TW, Baker RG. 1980. Palynology of Pinedale sediments, Devlins Park, Boulder County, Colorado. Arctic and Alpine Research 12: 319-333.

Lenart MT. 2003. A Comparative Study of Soil Disturbance from Uprooted Trees, and Mound and Pit Decay, in Puerto Rico and Colorado. Dissertation, University of Arizona, Tucson, Arizona.

Lorimer CG. 1977. The presettlement forest and natural disturbance cycle of northeastern Maine. Ecology 58: 139-148.

MacNish RD. 1966. The Cenozoic History of the Wet Mountain Valley, Colorado. Dissertation, University of Michigan, Ann Arbor, Michigan.

Madole RF. 1986. Lake Devlin and Pinedale glacial history, Front Range, Colorado. Quaternary Research 25: 43-54.

McConnell CW. 1988. Succession in Two Subalpine Forest Stands in Southern Colorado. Thesis, Duke University, Durham, North Carolina.

McFadden LD, Wells SG, Jercinovich MJ. 1987. Influence of eolian and pedogenic processes on the origin and evolution of desert pavements. Geology 15: 504-508.

Melton MA. 1965. Debris-covered hillslopes of the Arizona desert - consideration of their stability and sediment contribution. Journal of Geology 73: 715-729.

Mills HH. 1981. Boulder deposits and the retreat of mountain slopes, or 'gully gravure revisited'. Journal of Geology 89: 649-660.

Neiburger M, Edinger JG, Bonner W. 1973. Understanding Our Atmospheric Environment. WH Freeman: San Francisco, California.

Nelson AR, Millington AC, Andrews JT, Nichols H. 1979. Radio-carbon dated upper Pleistocene glacial sequence, Fraser Valley, Colorado Front Range. Geology 7: 410-414.

Osterkamp WR, Toy TJ. 1994. The healing of disturbed hillslopes by gully gravure. Geological Society of America Bulletin 106: $1233-1241$.

Patric JH, Evans JO, Helvey JD. 1984. Summary of sediment yield from forested land in the United States. Journal of Forestry 82(2): 101104.

Poesen JW, Torri D, Bunti K. 1994. Effects of rock fragments on soil erosion by water at different spatial scales: a review. Catena 23: 141166.

Putz FE. 1983. Treefall pits and mounds, buried seeds, and the importance of soil disturbance to pioneer trees on Barro Colorado Island, Panama. Ecology 64: 1069-1074.

Rapp A. 1960. Recent development of mountain slopes in Kärkevagge and surroundings, northern Scandinavia. Geografiska Annaler 42: 65-200. 
Reid LM. 1981. Sediment production from gravel-surfaced forest roads, Clearwater Basin, Washington. Publication FRI-UW-8108. Fisheries Resources Institution, University of Washington.

Schaetzl RJ, Johnson DL, Burns SF, Small TW. 1989. Tree uprooting: review of terminology, process, and environmental implications. Canadian Journal of Forest Research 19: 1-11.

Short SK. 1985. Palynology of Holocene sediments, Colorado Front Range: vegetational and treeline changes in the subalpine forest. American Association of Stratigraphic Palynologists Contribution Series 16: 7-30.

Short SK, Elias SA. 1987. New pollen and beetle analyses at the Mary Jane site, Colorado; evidence for late glacial tundra conditions. Geological Society of America Bulletin 98: 540-548.

Simanton JR, Renard KG, Christiansen CM, Lane LJ. 1994. Spatial distribution of surface surface rock fragments along catenas in semiarid Arizona and Nevada, USA. Catena 23: 29-42.

Strahler AN. 1957. Quantitative analysis of watershed geomorphology. Transactionsof the American Geophysical Union 38: 913-920.

Torres JA. 1994. Wood decomposition of Cyrilla racemiflora in a tropical montane Forest. Biotropica 26: 124-140.

Toy TJ, Osterkamp WR. 1999. The stability of rock-veneered hillslopes. International Journal of Sediment Research 14(4): 63-73.

Trewartha GT. 1954. An Introduction to Climate. McGraw-Hill: New York.

Wardle J. 1970. The ecology of Nothofagus solandri. IV. Growth and general discussion of parts I to IV. New Zealand Journal of Botany 4: 609-646.

Watanabe T. 1990. Relative dating methods mainly applied to glacial and periglacial Deposits. Quaternary Record 29: 49-77 (in Japanese).

Weber WA. 1976. Rocky Mountain Flora. Colorado Associated University Press: Boulder, Colorado.

Wells SG, McFadden LD, Poths J, Olinger CT. 1995. Cosmogenic ${ }^{3} \mathrm{He}$ surface-exposure dating of stone pavements: implications for landscape evolution in deserts. Geology 23: 613-616.

Whitney GG. 1986. Relation of Michigan's presettlement pine forests to substrate and disturbance history. Ecology 67: 1548-1559.

Whitney JW, Harrington CD. 1993. Relict colluvial boulder deposits as Paleoclimatic indicators in the Yucca Mountain region, southern California. Geological Society of America Bulletin 105: 1008-1018.

Williams S, Zimbelman JR. 1994. Desert pavement evolution: an example of the role of Sheetfloods. Journal of Geology 102: $243-248$. 